\title{
The Status and Social Role of Girl's Religious Educational Institutions of The Late XIX - The Beginning of The XX Century (On The Basis of Kazan, The Principal Town of Province)
}

\author{
Gulshat M. Mustafina ${ }^{* 1}$, Anton V. Yermoshin ${ }^{2}$, Ruzaliya I. Ziyatdinova ${ }^{3}$ \\ ${ }^{1,3}$ Kazan Federal University, Institute of International Relations, History and Oriental Studies \\ ${ }^{2}$ Kazan State Medical University, Department of Latin Language \\ Email: tggpu_history_russia@mail.Ru, Contact: +79053185274
}

Received: 21st October 2017 Accepted: 16th November 2017, Published: 31st December 2017

\begin{abstract}
The paper examines the status ofreligious girl's schools in the Russian Empire in the late XIX - early XX centuries, as well as their social role. In the period under consideration, the beginning of which is connected with the end of the "Great Reforms" era of the 1860s-1870s and the so-called "counter-reforms" of the 1880s, changes and status of girl's religious schools have been taking place during the evolution of the secular and religious education system, as well as changes in Russia's social life. These changes were analyzed by the authors of the paper on the basis of available published and archival sources concerning the activities of the two colleges of Kazan, the principal city of the province (the center of the government educational district and one of the dioceses of the Russian Orthodox Church): the Kazan Synodal Girl's School and the Kazan Diocesan Girl's School, with the involvement of modern methodological instrumentation of historical science.

The conclusions reached by the authors allowed them to talk about the increase in the social role of girl's religious schools during the period under consideration, and about their desire to go deeper into the all-Russian public education system and the changing social structure of the Russian society of the modernization era, which, however, was ambiguously perceived in society and provoked discussions on this issue.

The materials and conclusions of the paper can be useful to all those who are interested in the issues of Russia's social history, the regional history of the Russian province, the history of Church and public education, as well as to religious scholars, sociologists and managers of the education system.
\end{abstract}

Keywords: History, Public Education System, The Russian Empire, The Post-Reform period, The Era of Modernization, Girl's Religious Schools, Kazan, The Principal City of the Province.

\section{Introduction}

The system of girl's education in Russia was formed more slowly than the men's education, that was typical both for secular and church educational institutions. Looking to the history of the founding of Kazan Synodal Girl's School, it is necessary to view the prehistory of the colleges for the girl's of clergy estate. Girl's religious schools appeared in Russia only in the middle of the XIX century. Their contemporaries explained creation of such schools by the necessity: "Daughters of priests should not be given the education that is delivered in institutions established for girls of the nobility: the priests' wives should devote themselves to their family and rarely leave their home. Thus, the goal of their upbringing is to make them such wives who could be a pleasant companion to their husbands, help them in maintaining a church building in a decent order, prepare medicines for the sick, educate their children and keep their households at their best", while emphasizing that "woman's education in public institutions which was extended to many estates, did not concern only the clergy though it had the priority need to another estates"[1].

The manifestation of this approach was the decree of Emperor Nikolai I of 1843 on the opening of the first school for girls of clerical estate in Tsarskoe Selo settlement. Its charter and training programs should be a model for similar girl's educational institutions. The emperor ordered the expansion of the network of such schools by opening them "not in the monasteries, but according with the model of Tsarskoselsky School, for they must prepare girls for secular life, and not for reclusion" [3]. In 1853 such a school was opened in Kazan. It was intended for the daughters of priests from Kazan and six neighboring dioceses: Vyatka, Perm, Samara, Orenburg, Simbirsk and Astrakhan, so it was called "Okruzhny" ("District" school). The full course of the school was 6 years in three classes.

Thus, the creation of first Kazan Synodal Girl's School, like the rest in Russia, according to the idea of the creators did not pursue the goal of incorporating female representatives of clerical estate into an active social life of the Empire. On the contrary, it was recognized that it was necessary to educate them separately from girls from the nobility and other estates trained in the institutions of noble maidens and girl's gymnasiums, and the purpose of their training pursued limited estate interests: to prepare skillful housewives for family life at their husband-priests, to create their assistants in parish service.

The second school of this type - Kazan Diocesan Girl's School, was opened in 1890 . The following reasons for its foundation were pointed out in official sources of that time: since the Kazan Synodal Girl's School received the priests' daughters from several dioceses, and the number of places in it was limited, access to the school was denied to many girls from the families 
of the lower clergy of the Kazan diocese (deacons and psalm-readers). In this regard, it was decided to found a new educational institution for girls from the clerical estate [18]. Thus, the officially declared purpose was rather "quantitative" rather than "qualitative": this was not about structural and substantive differences between the new school and the first.

Yet the opening of the Diocesan Girl's School took the place in time with the era of active modernization of Russian society, which had an influence on the system of public education. As a result, contrary to official declarations, there has been a significant evolution of the social status of these educational institutions and their role in the life of society.

\section{Methods}

The functioning and evolution of the girl's religious education system in Kazan during the studied period is considered in this paper against the backdrop of political, social and religious-cultural processes taking place in Russian society in the late 19th and early 20th centuries. The comparative historical analysis of archival sources, materials of the periodical press and scientific literature, as well as the generalization and systematization of facts became the leading method.

Various aspects and levels of the education system in the context of the history of state institutions of prerevolutionary Russia and the domestic policy of autocracy as a whole were also considered in foreign, in particular, English-language Russian studies [13, 16]. These issues were also touched upon in domestic historiography $[5,6]$. The main conclusion of historiography regarding the issue under consideration was the statement of weak integration of girl's religious education in the social structure of Russian society as a whole and the educational system in particular. This is due to those declarative constants, which were named above. However, a systematic analysis of the school records (in archive files and diocesan periodicals), their curriculum and staff allowed the authors to correct these statements as applied to the period of Russian history in question.

\section{Results}

At the opening of the Kazan Synodal Girl's School, in accordance with its purpose, subjects such as the "Zakon Bozhiy" (consisting of the Sacred history of the Old and New Testaments, the Catechism, the doctrine of worship, and the history of the Church) and general educational disciplines such as Literature, Russian and Slavic languages, History of literature, Civil history (ancient, medieval and new), Universal and Russian geography, a full course of Arithmetic, Singing and Calligraphy, were included into its curriculum. Such disciplines as handicraft and economy were directed at preparing pupils for the role of mothers and wives [19]. To enter school it was necessary to have initial knowledge in the "Zakon Bozhiy", Russian and Slavic languages, and Arithmetic. At the same time, it was pointed out that "for admission to the school, children may be trained according to the training manuals and guides that are accepted in primary schools of different names (parochial, zemstvo, ministerial) [9, 15]. This meant that 9-10 years old girls entering the school had to own a considerable amount of knowledge from the primary school course. An analysis of these requirements, as well as the curriculum of the school [10], let us make a conclusion that it was a quite typical female general educational institution of the middle level, differing little from secular secondary schools (in which the "Zakon Bozhiy" was also taught in considerable volume) [7, 8]. Later the school program expanded due to new disciplines: Geometry, Physics and Pedagogy, which was caused by the decree of the Synod of 1873, according to which the school was given the right to produce worthy pupils "at the end of the full course in the title of home teachers" [11]. This de facto brought this type of educational institutions even closer together with girl's gymnasiums, having a 7-grade general education course with an additional 8th pedagogical class whose graduates got the right to teach in primary schools of various types, although in the hierarchy of educational institutions of the Russian Empire, girl's schools de jure stood below gymnasiums and institutes [20].

The situation was similar in the Kazan Diocesan Girl's School opened in 1890. The program for those entering it contained an indication that those who intended to enter the 1st class were tested in the full course of a one-year parochial school (on the basis of which this program was compiled). Basically, it repeated the program of the Kazan Synodal Girl's School, but in some aspects was its enhanced version [14].

The curriculum of the diocesan school included lessons in the "Zakon Bozhiy", the Russian language, Literature, Geography, Arithmetic, Didactics and Pedagogy, Hygiene, Physics, Civil history, Church singing, Calligraphy and Handiwork [2]. The study of foreign languages was paid and was not always available to pupils and their parents because of high cost. In this respect, religious schools were inferior to girl's gymnasiums and institutes of noble maidens.

An analysis of the state of both schools shows that the teachers who worked in them, in terms of their training level, were not very different from the teachers of the ministerial and private girl's gymnasiums, and a number of them combined work in these educational institutions of various departments that at the turn of the 19th and 20th centuries becomes quite common. Most of school teachers were not spokesmen of narrow-class interests, but belonged to democratically minded intelligentsia belonging to different social classes.

These circumstances led to the situation contrary to the initial intentions of the founders of this type of schools: their inner atmosphere educated the pupils often in the same spirit and direction as in secular educational institutions. The preparedness of the graduates to teach in primary schools (not only parochial, but also county and ministerial schools) determined their inclusion in the advanced pedagogical circles of Russia of the era of modernization. 


\section{Discussion}

Discussion about the status and social role of girl's religious schools has been started by contemporaries who didn't ignore the fact that those schools were close to girl's gymnasiums and other secondary educational institutions for girls. Advanced members of the public, including those from the clerical order, advocated for overcoming the class closeness of these schools, for their more intensive integration into the public education system of the Russian Empire. A vivid illustration of this discussion was a sharp tone on the exchange of views on the shortcomings of the educational process at Kazan Diocesan Girl's School in comparison with secular schools between the representative of the liberal wing of the Kazan clergy, Porfiry Rufimsky, and the inspector of the Diocesan School, Nikolai Vladimirsky, reflected in "Kazan Diocese News" newspaper.

This issue was raised in the course of preparing the reform of the Russian education system at the beginning of the 20th century, since this system was complex and confusing: it included a wide variety of educational institutions, often with their vague reference to primary, secondary or higher schools (for example, the name "institute" could belong to both secondary and higher educational institution, the name "school" could be applied to both primary and secondary schools, etc.). Attempts to build a clear and harmonious structure of Russian schools inevitably raised the problem of equalizing girl's religious schools with girl's gymnasiums, both in the number of classes and in the rights of graduates [4, 17]. However, the process of this reform was not completed in connection with the First World War that began in 1914 and the revolution that followed in 1917.

On the eve of the revolutionary events, as well as in the period between the February and October revolutions of 1917, this question was raised in the church community as well. At the same time, there were completely different points of view: from the need to protect religious girl's schools as much as possible from the secular school community to the need to establish their mutual correlation, the equation in programs and rights, and even the transfer of these general schools of the Synod to the Ministry of Education and transformation to ministerial girl's gymnasiums [12]. The implementation of these projects was also hampered by a change in the nature of relations between Church and State and school policy after the establishment of Soviet power: the abolition of class and religious educational institutions, the introduction of a "single labor school", etc. At the same time, researchers of the Soviet period were inclined to exaggerate the "reactionary character" of the religious educational institutions, giving a positive assessment to the fact of their liquidation. In modern Russian historiography, these estimates are revised.

\section{Summary}

First of all, it must be emphasized that the very concept of a "religious educational institution" needs to be clarified and differentiated. When it comes to boys' religious educational institutions, they are implied not so much estate but professional schools. Religious seminaries and especially theological academies were called "religious" not so much because of the class belonging of their students and their own departmental affiliation, but because of their professional orientation: they primarily prepared graduates for the clergy, cadres of clergymen and various employees of church institutions. But this doesn't concern girl's religious educational institutions. Due to the fact that a woman in the Orthodox tradition could not become a clergywoman, and her membership in the religious estate was determined not by professional duties but by marital status (a clergymen's daughter and wife), one cannot talk about girl's religious schools as professional schools. These were general schools that belonged to the Synodal department. And their general educational character inevitably brought them closer to similar girl's schools of other departments (the Ministry of Education, the Department of the institutions of Empress Maria, etc.). This circumstance of an internal, content character led to the evolution of the social role of these schools, which was mentioned above.

The second catalyst for this evolution having an external, systemic nature, was the development of a network of primary schools for boys and girls actively opened by the zemstvos [21], and also parochial schools by the Synod, the mass expansion of which occurred during the period of holding office by the Chief Prosecutor of the Synod of K. P. Pobedonostsev (1880-1905). This led to the demand for graduates of girl's religious schools to be not only housewives in the families of parish priests (which was declared the goal of these schools at the initial stage of their existence), but also teachers of various primary schools (both in the Synod and in the Ministry of Education). This brought them into the circle of the rural, and, in part, urban intelligentsia, increased their own social status and the status of religious girl's schools, bringing them closer to girl's gymnasiums with a pedagogical class, to girl's institutes and girl's teacher's seminaries. These changes took up the state, the Church and society with the matter of the official equation of the status of these schools, but for reasons beyond the control of the educational institutions themselves, this issue was not resolved due to a change in the paradigm of church-state relations in Russia after the 1917 revolution.

\section{Conclusions}

Being estate-based educational institutions, girl's religious schools at the same time were a part of the state education system. Accordingly, they fulfilled social tasks determined by state policy in the field of education. However, the analysis of their activities shows that, on the one hand, the principle of 
stratification on estates (the expansion of the circle of students, including those from another social classes) has been less strictly observed, on the other, educational activity and the status of graduates have increasingly brought them closer to secular girl's educational institutions.

\section{Acknowledgements}

The work is carried out according to the Russian Government Program of Competitive Growth of Kazan Federal University.

\section{References}

[1] Dneprov E. D., Usacheva R. F. Girl's Education in Russia. Moscow, 2009. - 275 p. P. 95.

[2] Extract from the Report on the condition of the Kazan Diocesan Girl's School for Educational and Upbringing Work for the year 1897/8. Kazan, 1899. $28 \mathrm{p}$.

[3] Kazan Synodal Girl's School. Kazan, 1873. - 12 p. P. 1.

[4] Kornilova I. V. Training of Teachers in the Kazan Province in the Pre-revolutionary Period. Saarbrucken, 2012. - $211 \mathrm{p}$.

[5] Leikina-Svirskaya V. R. The Russian Intelligentsia in 1900-1917. Moscow, 1981. - 285 p.

[6] Mironov B. N. Social History of Russia during the Period of the Empire (XVIII - early XX century). Genesis of Personality, Democratic Family, Civil Society and the Rule of Law. In 2 volumes. V. 2. St. Petersburg, 2000. - 566 p.

[7] Mustafina G. M., Nikolaeva N. G., Yermoshin A. V. "Teaching Religion and Classical Languages in Russian Gymnasiums in the Middle of XIX Beginning of the XX Century: Searching for a Harmonic Correlation”, Man in India, vol. 97, № 8, pp. 19-28, 2017.

[8] Mustafina G. M., Yermoshin A. V. "The Development of Educational and Methodical Framework of the Religious Educational Process in Secular Secondary Schools during the Modernization of the Russian Society (The Second Half of the 19th Early 20th Centuries)", Journal of Sustainable Development, vol. 8, № 4, pp. 86-94, 2015.

[9] National Archive of the Republic of Tatarstan. Fund 475. Inventory 1. File 17. Sheets 1-69.

[10] National Archive of the Republic of Tatarstan. Fund 475. Inventory 1. File 45. Sheets 1-36.

[11] National Archive of the Republic of Tatarstan. Fund 475. Inventory 1. File 75. Sheet 64.

[12] Comments of Diocesan Bishops on the Issue of Church Reform. In 2 parts. Moscow, 2004. - 1031, $1056 \mathrm{p}$.

[13] Pogger H. Russia in the Age of Modernization and Revolution: 1881-1917. London; New York, 1983. $323 \mathrm{p}$.

[14] The Program of Tests for Enrolling in the 1st Class of the Kazan Diocesan Girl's School. Kazan, 1911. - 5 p.
[15] The Program of Study Subjects for Admission to the 1st Class of the Kazan Synodal Girl's School. Kazan, w/o a year. - 3 p.

[16] The Cambridge History of Russia. 1869-1917. London, 2006. - $801 \mathrm{p}$.

[17] Utrobina I. V. Pedagogical Education in the Kazan Province in the Last Quarter of the XIX - Early XX Centuries. Thesis for the Degree of Candidate of Historical Sciences. Kazan, 1999. - 232 p.

[18] Vinogradov N., "The Opening of the Kazan Diocesan Girl's School", Kazan Diocese News, No. 19, pp. 463-471, 1890.

[19] Graduation of the 12th Course Students from the Kazan Synodal Girl's School. Kazan, 1881-1883. - 20 p. P. 2.

[20] Yermoshin A. V., Mustafina G. M. "The Problem of Correlation of Secular and Religious Education in the Context of Reforming of Secondary School in the Post-reform Period", Philology and Culture, vol. 21, No. 3, pp. 116-121, 2010.

[21] Zheleznyakova Yu. E. Zemstvo School of the Kazan Province: 1865-1917. Kazan, 2005. 204 pp. 